\title{
Effects of micronized-roasted coffee concentration and temperature process on technological properties of rice-based extruded
}

Efeitos da concentração do café torrado micronizado e temperatura de processo nas propriedades tecnológicas de extrusados à base de arroz

Efectos de la concentración de café tostado micronizado y de la temperatura del proceso sobre las propiedades tecnológicas de los extruidos a base de arroz

Received: 03/31/2021 | Reviewed: 04/10/2021 | Accept: 04/11/2021 | Published: 04/22/2021

Ulliana Marques Sampaio

ORCID: https://orcid.org/0000-0003-4664-7988 State University of Campinas, Brazil E-mail: ulliana.unicamp@gmail.com

Pedro Campelo

ORCID: https://orcid.org/0000-0002-5137-0162 Federal University of Amazonas, Brazil E-mail: pedrocampelo@ufam.edu.br

Yoon Kil Chang

ORCID: https://orcid.org/0000-0002-5897-1681 State University of Campinas, Brazil E-mail: yokic@unicamp.br

Maria Teresa Pedrosa Silva Clerici ORCID: https://orcid.org/0000-0002-8445-336X State University of Campinas, Brazil E-mail: mclerici@unicamp.br

\begin{abstract}
New ingredients have been used in extruded products to increase the healthiness and regionalization of these products. However, the process variables that can interfere with the technological quality of the product should be studied, aimed at good acceptance by consumers. This study aimed to evaluate the effects of the concentration of micronized roasted coffee (MRC) and the barrel temperature on the technological properties of rice-based extrudates. The extrudates were made with 3 and $8 \%$ MRC to replace rice flour and processed in a mono-extruder at 140 and $180{ }^{\circ} \mathrm{C}$. They were characterized for color, expansion index, hardness, bowl-life, porosity, water absorption index, and solubility index, and paste properties. To assess the effects of the process variables, analysis of variance, and Scott-Knott test ( $\mathrm{p}<0.05)$ were applied to compare the means. The increase in MRC concentration reduced the color parameters and hardness, while the increase in temperature affected the expansion index. A joint effect of the variables concentration and temperature was observed for the other properties evaluated. The study showed that MRC is a potential source of fibers and natural pigments, with a direct effect on the main technological properties of the final product.
\end{abstract}

Keywords: Coffee; Extrusion cooking; Physical process; Technological properties.

\section{Resumo}

Novos ingredientes em produtos extrusados estão sendo inseridos para aumentar a saudabilidade e a regionalidade destes produtos. Entretanto, para se obter um produto com boa aceitação por parte dos consumidores, é necessário compreender primeiro quais variáveis de processo podem interferir na qualidade tecnológica do mesmo. Este trabalho teve como objetivo avaliar os efeitos da concentração de café torrado e micronizado (MRC) e da temperatura nas propriedades tecnológicas de extrusados à base de arroz. Os extrusados foram elaborados com 3 e $8 \%$ de MCR em substituição à farinha de arroz e processados em extrusora monorosca a 140 e $180^{\circ} \mathrm{C}$. Estes foram avaliados quanto à cor, índice de expansão, dureza, bowl-life, porosidade, índices de absorção e solubilidade em água e propriedades de pasta. Para avaliar os efeitos das variáveis de processo foi aplicada análise de variância e teste Scott-Knott $(\mathrm{p}<0.05)$ para comparação das médias. O aumento da concentração de café reduziu os valores dos parâmetros de cor e a dureza, já o aumento da temperatura influenciou na expansão. Para as demais propriedades avaliadas, as duas variáveis influenciaram em conjunto. $\mathrm{O}$ estudo mostrou que MRC é fonte potencial de fibras e de pigmentos naturais, apresentando uma influência direta nas principais propriedades tecnológicas do produto final.

Palavras-chave: Café; Extrusão termoplástica; Processo físico; Propriedades tecnológicas. 


\section{Resumen}

Nuevos ingredientes vienen siendo adicionados en productos extruidos a fin de aumentar su salubridad y regionalidad. Sin embargo, para obtener un producto con una buena aceptación de parte de los consumidores, primero es necesario comprender qué variables del proceso pueden interferir en la calidad tecnológica del mismo. Este trabajo tuvo como objetivo evaluar los efectos de la concentración de café tostado y micronizado (MRC) y de la temperatura en las propiedades tecnológicas de los extruidos a base de arroz. Los extrusados fueron elaborados con 3 y $8 \%$ de MCR como sustituto de la harina de arroz, y después fueron procesados en extrusora mono-tornillo a 140 y $180^{\circ} \mathrm{C}$. Se evaluaron sus características como el color, índice de expansión, dureza, bowl-life, porosidad, índices de absorción y solubilidade en agua, y propiedades de pasta. Para evaluar los efectos de las variables de proceso fue aplicado el análisis de varianza y test de Scott-Knott $(\mathrm{p}<0.05)$ de comparaciones múltiples. El aumento de la concentración de café redujo los valores de los parámetros de color y dureza, mientras que el aumento de la temperatura influyó en la expansión. En las demás propiedades evaluadas, las dos variables influyeron en conjunto. El estudio mostro que MRC es una fuente potencial de fibras y pigmentos naturales, que tiene una influencia directa en las principales propiedades tecnológicas del producto final.

Palabras clave: Café; Extrusión termoplástica; Proceso físico, Propiedades tecnológicas.

\section{Introduction}

Coffee is one of the main raw materials produced in Brazil, which is the world's largest producer and exporter (ICO, 2020). Due to its unique sensory characteristics, coffee is present in the daily lives of millions of people around the world. The popularity of coffee is also based on its health benefits. Coffee has been extensively studied for its chemical composition and functional properties, being a natural source of fibers and antioxidant compounds (Pereira et al., 2020). Although coffee is mostly consumed as a beverage, it can also be a potential ingredient for extruded cereal products.

There is a growing concern for healthier eating, which has become more evident with the Covid-19 pandemic (Euromonitor, 2020). Ready-to-eat extruded products, such as extrudates and snacks, can be a practical alternative to meet everyday life demands. The insertion of coffee into these products can provide a combination of flavour and healthiness, which are, in that order, the first two factors that consumers understand by "eating well", as reported by The Food Market Insitute (2019).

However, the incorporation of new ingredients into cereal-based extruded products is still a challenge. New ingredients can negatively alter the technological characteristics of the final product, influencing the consumers' acceptance (Shah et al., 2019). Therefore, the effects of the parameters involved in the extrusion process should be studied to provide a quality product from the physicochemical and sensory point of view (Obradović et al., 2014).

Response surface methodology has been used as a statistical tool to study the introduction of new ingredients. However, regression models are effective only within the experimental range of the variables, without extrapolation (Dean et al., 2017). Therefore, preliminary experiments are necessary to find the most important variables and the appropriate intervals to determine the experimental design and optimization (Eerikainen \& Linko, 1989).

The intervals of these factors must be wide and proportional enough to determine the actual effects of each variable to obtain the best responses for the dependent variables. In this way, this study aimed to evaluate the effect of micronized-roasted coffee concentration and barrel temperature on the technological properties of rice-based extruded products.

\section{Materials and Methods}

\subsection{Raw materials and micronized-roasted coffee (MRC) preparation}

Rice flour (RF) was provided by SL Alimentos (Mauá da Serra, Brazil), and green coffee (Coffea arabica) by Ipanema Coffees (Alfenas, Brazil). Green coffee beans were subjected to a medium roasting process for $180{ }^{\circ} \mathrm{C}$ at 15 min. After the treatment, the coffee was ground until reaching a particle size of $150 \mu \mathrm{m}$ and subsequently stored in vacuum plastic bags at -18 ${ }^{\circ} \mathrm{C}$. 
The RF and the micronized-roasted coffee (MRC) presented, respectively, the following average composition ( $\mathrm{g} / 100 \mathrm{~g}$ sample) on a dry basis: $0.69 \pm 0.02$ and $4.40 \pm 0.01 \mathrm{ash}, 1.11 \pm 0.01$ and $13.28 \pm 0.28$ crude fat, $10.28 \pm 0.18$ and $14.63 \pm 0.15$ protein, $0.00 \pm 0.00 \mathrm{~g}$ and $56.53 \pm 0.77$ total dietary fibers, and $87.93 \pm 0.18$ and $11.17 \pm 0.77$ digestible carbohydrates.

\subsection{Extrusion cooking}

The extrusion was conducted using a single screw extruder (Brabender, Duisburg, GNF), keeping constant the compression ratio $(3: 1)$, die diameter $(3 \mathrm{~mm})$, screw speed $(120 \mathrm{rpm})$, blend moisture $(16 \%)$, and temperatures of the first zone $\left(70{ }^{\circ} \mathrm{C}\right)$ and the second zone $\left(120^{\circ} \mathrm{C}\right)$. Different MRC concentrations $(3$ and $8 \% \mathrm{w} / \mathrm{w})$ and different barrel temperature of the third zone $\left(140\right.$ and $180{ }^{\circ} \mathrm{C}$ ) was varied (Table 1), based on the fiber content of blends and process temperature used to produce directly expanded products. After the thermal process, the extrudates were immediately transferred to an oven at $50{ }^{\circ} \mathrm{C}$ until the moisture reached below $6 \%$. The products were then stored in plastic bags for further analysis.

Table 1. Experimental design of rice flour-micronized-roasted coffee extruded.

\begin{tabular}{ccc}
\hline Assays & RF:MRC $(\boldsymbol{\%})$ & Temperature $\left({ }^{\circ} \mathbf{C}\right)$ \\
\hline C3-140 & $97: 3$ & 140 \\
C3-180 & $97: 3$ & 180 \\
C8-140 & $92: 8$ & 140 \\
C8-180 & $92: 8$ & 180 \\
\hline
\end{tabular}

Source: Authors.

\subsection{Technological properties of extruded products}

\subsubsection{Expansion index $(\mathrm{EI})$}

Ten random extrudate samples from each treatment were subjected to diameter measurements using a Craftsman caliper. The EI was determined by the ratio between the diameter of the extrudate and the diameter of the die (Faubion $\&$ Hoseney, 1986).

\subsubsection{Hardness}

The hardness was determined using a TA-XT2i texture analyzer (Stable Micro Systems Ltd., Godalming, Surrey, U.K.) with a Warner-Bratzler shear blade with a "V" shape probe (Paula \& Conti-Silva, 2014). The extrudates were cut to $5 \mathrm{~cm}$ in length, and the test conditions were probe distance of $20 \mathrm{~mm}$, pre-test speed of $2 \mathrm{~mm} / \mathrm{s}$, test speed of $1 \mathrm{~mm} / \mathrm{s}$, and post-test speed of $1 \mathrm{~mm} / \mathrm{s}$. The hardness was defined as the peak force $(\mathrm{N})$ required to rupture the sample, and the results were represented by an average of ten measurements.

\subsubsection{Bowl-life}

The bowl-life was determined according to Oliveira et al. (2017). The extrudates were immersed in $100 \mathrm{~mL}$ of whole milk at $10{ }^{\circ} \mathrm{C}$ for 3 minutes and then drained for 10 seconds. After that, the analysis was conducted in the same conditions described in item 2.3.2. 


\subsubsection{Cross-section images analysis}

The images of extrudates were evaluated according to Oliveira et al. (2015). The extrudates were cut $(n=10)$ in half using a Stanley knife. The images of cross-sections of the extrudates were captured using a scanner equipped with the HP PrecisoScan software version Pro 3.1 (HP Scanjet 4400C, Hewlett-Packard, USA), using a black background paper. Diameter $(\mathrm{mm})$, perimeter $(\mathrm{mm})$, area $\left(\mathrm{mm}^{2}\right)$, the circularity of the particles $(0-1)$, and porosity $(\%)$ were determined, and the mean values were subjected to statistical analysis.

\subsubsection{Instrumental color}

The color of raw materials and extrudates was determined using a MiniScan HUNTERLAB CR-400 spectrophotometer (Konica Minolta Sensing Americas), according to the CIELab system. L* represents the lightness of the sample, with values between 0 (black) and 100 (white), $\mathrm{a}^{*}$ and $\mathrm{b}^{*}$ representing the color ranging from red $\left(+\mathrm{a}^{*}\right)$ to green $\left(-\mathrm{a}^{*}\right)$ and from yellow $\left(+\mathrm{b}^{*}\right)$ to blue (-b*), respectively. The illuminant D65 was used, and the readings were performed in triplicate at three different points, and the values were expressed as averages.

\subsubsection{Water absorption index (WAI) and water solubility index (WSI)}

The water absorption and solubility indices were determined according to (Anderson, 1982). Initially, the extrudates were ground until reaching a particle size of $60 \mathrm{mesh}$. Then, $2.5 \mathrm{~g}$ was suspended in $30 \mathrm{~mL}$ of distilled water in a centrifuge tube. The suspension was stirred for 30 minutes intermittently and centrifuged for $10 \mathrm{~min}$ at $3000 \mathrm{x}$. The supernatant was transferred to an aluminum plate and dried in an air circulation oven at $105^{\circ} \mathrm{C}$ for 4 hours. The WAI corresponded to the ratio of the weight of the centrifuged residue to the initial weight of the sample. The WSI corresponded to the ratio of the weight of the evaporated residue to the initial weight of the sample, in percentage. All determinations were carried out in triplicate, and the results were expressed on a dry basis.

\subsubsection{Pasting properties}

The pasting viscosity was determined using the Rapid Visco Analyzer (RVA 4500, Perten Instruments, Australia) and the software Thermocline for Windows, according to the following procedures (AACCI, 2010): the suspension was heated from 25 to $95{ }^{\circ} \mathrm{C}$ at $14{ }^{\circ} \mathrm{C} / \mathrm{min}$ (after equilibrium for $2 \mathrm{~min}$ at $25^{\circ} \mathrm{C}$ ), held at $95{ }^{\circ} \mathrm{C}$ for $5 \mathrm{~min}$, and cooled at $14{ }^{\circ} \mathrm{C} / \mathrm{min}$ to $25{ }^{\circ} \mathrm{C}$, totaling $20 \mathrm{~min}$ of analysis. The parameters evaluated were: cold peak viscosity, raw peak viscosity, hold peak viscosity, breakdown viscosity, final viscosity, and setback viscosity. All determinations were performed in triplicate.

\subsection{Data analysis}

The technological characterization of the extrudates was evaluated by analysis of variance (ANOVA) at a 5\% level of significance, using the Scott-Knott test to compare means through software SISVAR (version 5.6).

\section{Results and Discussion}

\subsection{Expansion index (EI)}

The expansion index is one of the most important physical characteristics of extruded products and is related to the formation of air bubbles that generate a porous, expanded, and sponge-like structure (Bouvier \& Campanella, 2014). Significant differences ( $\mathrm{p}<0.05$ ) were observed between the treatments, with EI ranging between 2.65 and 3.05 (Table 2). The graphs (Figure 1) and the ANOVA table for main effects (Table 3 ) showed a significant effect $(p<0.05)$ of the temperature and the interaction concentration $\mathrm{X}$ temperature. 
Research, Society and Development, v. 10, n. 4, e54510414529, 2021

(CC BY 4.0) | ISSN 2525-3409 | DOI: http://dx.doi.org/10.33448/rsd-v10i4.14529

Table 2. Technological properties of rice-micronized-roasted coffee extrudates ${ }^{1}$.

\begin{tabular}{|c|c|c|c|c|}
\hline \multirow{2}{*}{ Properties } & \multicolumn{4}{|c|}{ Assays } \\
\hline & C3-140 & C3-180 & C8-140 & C8-180 \\
\hline Expansion index & $2.70 \pm 0.24^{b}$ & $2.77 \pm 0.27^{\mathrm{b}}$ & $3.05 \pm 0.18^{\mathrm{a}}$ & $2.65 \pm 0.24^{b}$ \\
\hline Hardness (N) & $30.43 \pm 3.96^{\mathrm{a}}$ & $27.06 \pm 3.62^{\mathrm{a}}$ & $22.76 \pm 3.87^{\mathrm{b}}$ & $22.77 \pm 3.23^{\mathrm{b}}$ \\
\hline Bowl-life (N) & $22.18 \pm 2.10^{\text {n.s. }}$ & $22.95 \pm 2.77^{\text {n.s. }}$ & $21.11 \pm 2.09^{\text {n.s. }}$ & $22.94 \pm 3.47^{\text {n.s. }}$ \\
\hline \multicolumn{5}{|l|}{ Cross-section } \\
\hline Diameter (mm) & $7.80 \pm 0.22^{\mathrm{a}}$ & $8.00 \pm 0.23^{\mathrm{a}}$ & $6.79 \pm 0.30^{c}$ & $7.36 \pm 0.12^{\mathrm{b}}$ \\
\hline Perimeter (mm) & $26.17 \pm 0.62^{\mathrm{a}}$ & $26.32 \pm 0.75^{\mathrm{a}}$ & $23.13 \pm 0.80^{c}$ & $24.02 \pm 0.52^{b}$ \\
\hline Area $\left(\mathrm{mm}^{2}\right)$ & $49.23 \pm 2.37^{\mathrm{a}}$ & $50.22 \pm 2.82^{\mathrm{a}}$ & $38.52 \pm 2.94^{c}$ & $41.92 \pm 1.75^{\mathrm{b}}$ \\
\hline Extruded circularity & $0.90 \pm 0.01^{\text {n.s. }}$ & $0.90 \pm 0.02^{\text {n.s. }}$ & $0.91 \pm 0.01^{\text {n.s. }}$ & $0.91 \pm 0.02^{\text {n.s. }}$ \\
\hline Cell circularity & $0.36 \pm 0.08^{\mathrm{a}}$ & $0.30 \pm 0.07^{\mathrm{b}}$ & $0.26 \pm 0.07^{b}$ & $0.30 \pm 0.09^{\mathrm{b}}$ \\
\hline Porosity (\%) & $44.48 \pm 3.19^{\text {n.s. }}$ & $47.39 \pm 7.03^{\text {n.s. }}$ & $52.68 \pm 6.50^{\text {n.s. }}$ & $50.92 \pm 11.81^{\text {n.s. }}$ \\
\hline \multicolumn{5}{|l|}{ Color } \\
\hline $\mathrm{L}^{*}$ & $68.16 \pm 0.22^{\mathrm{a}}$ & $67.04 \pm 0.71^{\mathrm{a}}$ & $64.82 \pm 0.66^{\mathrm{b}}$ & $61.90 \pm 0.52^{\mathrm{c}}$ \\
\hline$a^{*}$ & $6.32 \pm 0.09^{\mathrm{d}}$ & $6.65 \pm 0.17^{\mathrm{c}}$ & $7.09 \pm 0.20^{\mathrm{b}}$ & $7.72 \pm 0.09^{\mathrm{a}}$ \\
\hline $\mathrm{b}^{*}$ & $19.67 \pm 0.07^{\text {n.s. }}$ & $19.57 \pm 0.20^{\text {n.s. }}$ & $19.34 \pm 0.25^{\text {n.s. }}$ & $19.03 \pm 0.22^{\text {n.s. }}$ \\
\hline WAI & $7.57 \pm 0.09^{\mathrm{a}}$ & $6.19 \pm 0.03^{b}$ & $6.40 \pm 0.56^{\mathrm{b}}$ & $5.83 \pm 0.03^{b}$ \\
\hline WSI (\%) & $4.36 \pm 0.41^{\mathrm{b}}$ & $5.51 \pm 0.02^{\mathrm{a}}$ & $5.64 \pm 0.31^{\mathrm{a}}$ & $5.61 \pm 0.01^{\mathrm{a}}$ \\
\hline
\end{tabular}

${ }^{1}$ Values are means \pm standard deviations of triplicate trials. Means with different letters within the same line are significantly different by Scott-Knott test $(\mathrm{p}<0.05)$. ns-not significant.

Source: Authors.

Concerning the barrel temperature, a greater difference was observed at $140{ }^{\circ} \mathrm{C}$ for both $\mathrm{MRC}$ concentrations, with a greater EI for the concentration of $8 \%$ (Figure 1). However, this behavior changed with increasing the temperature to $180{ }^{\circ} \mathrm{C}$, and the EI values were statistically equal, regardless of the MRC concentration. The expansion index of the extrudates can be improved by increasing the temperature to an ideal point followed by a decrease, and the peak temperature depends on the chemical composition of the blends (Bouvier \& Campanella, 2014). 
Figure 1. Effects of MRC concentration and process temperature on technological properties of rice-based extrudates.
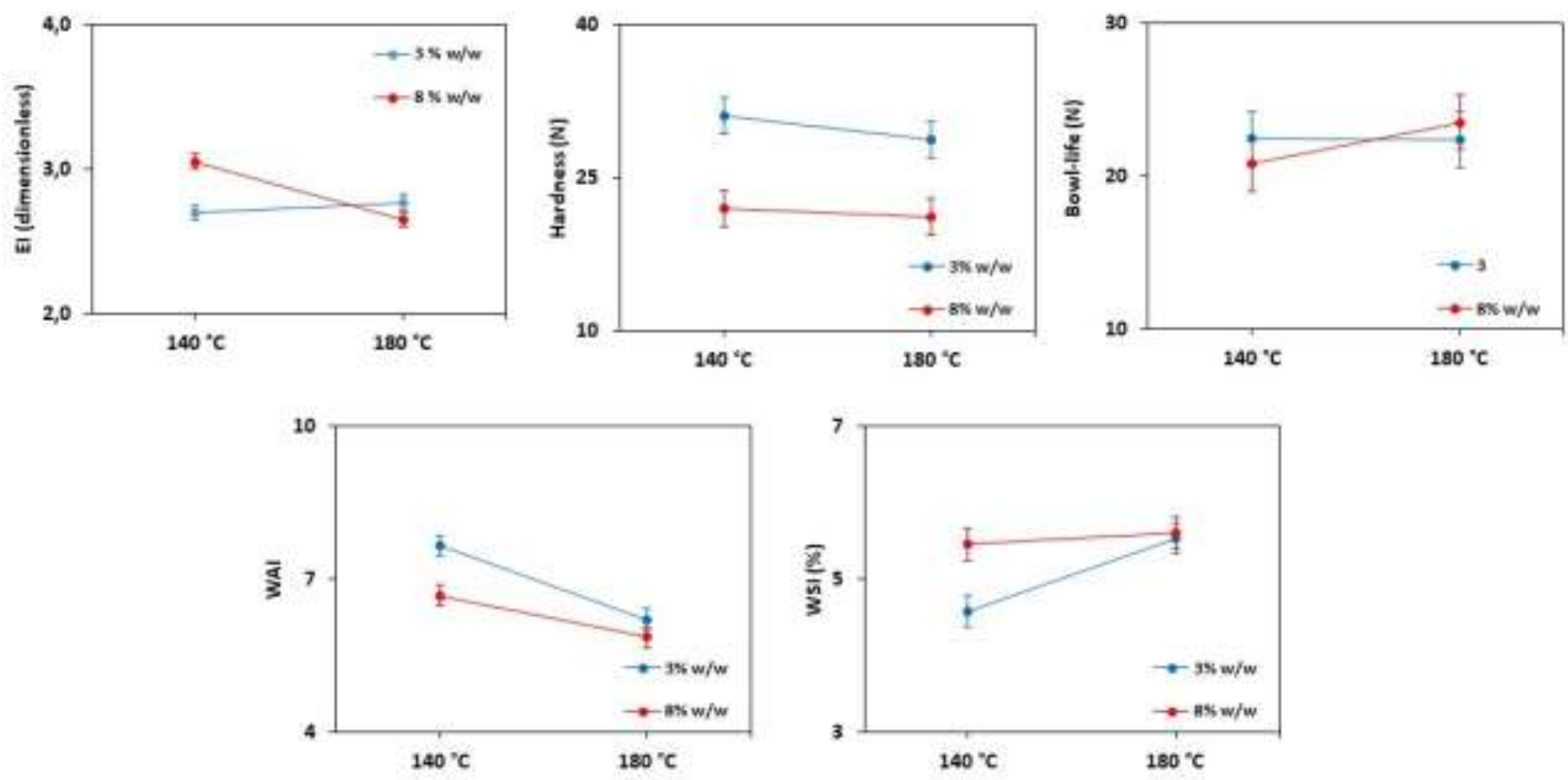

Source: Authors.

Robin et al. (2012) reported that fibers can form a matrix with starch and water, leading to the starch dilution or breakage of the bubble wall. In the present study, the bubbles did not reach their maximum growth and suffered a premature collapse, resulting in a product with less expansion index due to the presence of MRC. This trend was also observed in rice and roasted coffee blends (Silva et al., 2013) and sorghum and roasted coffee blends (Chávez et al., 2017).

However, a higher EI was observed for C8-140, probably due to the interaction concentration X temperature; once roasted coffee, in addition to insoluble fibers, also has a significant concentration of soluble fibers that favors expansion (Robin et al. 2012). As reported by Silván et al. (2010), soluble fibers content in coffee can present a mean value of $64.9 \mathrm{mg} .100 \mathrm{~g}^{-1}$. The micronization processing of coffee may also have favored the formation of soluble fibers through the physical disruption of the molecular structure of insoluble fibers, as was also reported by Zhu et al. (2014) in the micronization of buckwheat hulls.

\subsection{Hardness}

The hardness of the expanded extrudates is a noticeable and striking attribute for consumers, with an essential role in this type of product. It is correlated with the expansion and the cellular structure of the product (Dalbhagat et al., 2019) once the porosity and uniformity of the air bubbles formed in the extrusion can increase or reduce hardness (Ding et al., 2005). In addition to the process parameters, the chemical composition of the ingredients also interferes with this property, as also observed for EI (Bouvier \& Campanella, 2014).

A significant difference in the texture parameters was observed between treatments $(\mathrm{p}<0.05)($ Table 2$)$, with a significant effect of the MRC concentration, as shown in the results of ANOVA (Table 3). In spite of the known negative impact of insoluble fiber on extrudate hardness, Figure 1 shows that the increase in MRC concentration reduced the hardness values. According to Riaz \& Rockey (2012), the smaller particle size of the raw material containing fiber can reduce the negative impacts on this property. Also, Robin et al. (2012) reported that increasing the contact surface between fiber and starch can improve the physicochemical compatibility between them, directly affecting the expansion index and texture of the final product. 
Table 3. Analysis of variance (ANOVA) of the technological properties of rice-micronized-roasted coffee extrudates.

\begin{tabular}{|c|c|c|c|c|c|c|}
\hline Parameters & Source & SS & df & MS & F-value & $\mathbf{P}$ \\
\hline \multirow[t]{5}{*}{ Expansion index } & Intercept & 311,92 & 1 & 311,92 & 5703,64 & $<0,0000^{*}$ \\
\hline & $\mathrm{C}$ & 0,13 & 1 & 0,13 & 2,42 & 0,1287 \\
\hline & $\mathrm{T}$ & 0,27 & 1 & 0,27 & 4,98 & $0,0319^{*}$ \\
\hline & $\mathrm{C} * \mathrm{~T}$ & 0,55 & 1 & 0,55 & 10,10 & $0,0030^{*}$ \\
\hline & Error & 1,97 & 36 & 0,06 & & \\
\hline \multirow[t]{5}{*}{ Hardness } & Intercept & 39684,93 & 1 & 39684,93 & 818,756 & $<0,0000^{*}$ \\
\hline & C & 1032,02 & 1 & 1032,02 & 21,29 & $<0,0000^{*}$ \\
\hline & $\mathrm{T}$ & 38,02 & 1 & 38,02 & 0,78 & 0,3796 \\
\hline & $\mathrm{C}^{*} \mathrm{~T}$ & 10,22 & 1 & 10,22 & 0,21 & 0,6479 \\
\hline & Error & 2714,30 & 56 & 48,47 & & \\
\hline \multirow[t]{5}{*}{ Bowl-life } & Intercept & 13941,07 & 1 & 13941,07 & 3812,57 & $<0,0000^{*}$ \\
\hline & $\mathrm{C}$ & 0,42 & 1 & 0,42 & 0,12 & 0,7368 \\
\hline & $\mathrm{T}$ & 12,28 & 1 & 12,28 & 3,36 & 0,0794 \\
\hline & $\mathrm{C}^{*} \mathrm{~T}$ & 13,61 & 1 & 13,61 & 3,72 & 0,0656 \\
\hline & Error & 87,76 & 24 & 3,66 & & \\
\hline \multirow[t]{5}{*}{ Diameter } & Intercept & 2241,68 & 1 & 2241,68 & 42974,01 & $<0,0000^{*}$ \\
\hline & $\mathrm{C}$ & 6,75 & 1 & 6,75 & 129,45 & $<0,0000^{*}$ \\
\hline & $\mathrm{T}$ & 1,47 & 1 & 1,47 & 28,08 & $<0,0000^{*}$ \\
\hline & $\mathrm{C}^{*} \mathrm{~T}$ & 0,33 & 1 & 0,33 & 6,40 & $0,0159^{*}$ \\
\hline & Error & 1,88 & 36 & 0,05 & & \\
\hline \multirow[t]{5}{*}{ Perimeter } & Intercept & 24823,21 & 1 & 24823,21 & 53122,23 & $<0,0000^{*}$ \\
\hline & $\mathrm{C}$ & 71,26 & 1 & 71,26 & 152,49 & $<0,0000^{*}$ \\
\hline & $\mathrm{T}$ & 2,70 & 1 & 2,70 & 5,77 & $0,0216^{*}$ \\
\hline & $\mathrm{C}^{*} \mathrm{~T}$ & 1,39 & 1 & 1,39 & 2,97 & 0,0933 \\
\hline & Error & 16,82 & 36 & 0,47 & & \\
\hline \multirow[t]{5}{*}{ Area } & Intercept & 80892,22 & 1 & 80892,22 & 12788,51 & $<0,0000 *$ \\
\hline & $\mathrm{C}$ & 903,74 & 1 & 903,74 & 142,87 & $<0,0000^{*}$ \\
\hline & $\mathrm{T}$ & 48,13 & 1 & 48,13 & 7,61 & $0,0091 *$ \\
\hline & $\mathrm{C}^{*} \mathrm{~T}$ & 14,60 & 1 & 14,60 & 2,31 & 0,1374 \\
\hline & Error & 227,71 & 36 & 6,33 & & \\
\hline \multirow[t]{5}{*}{$\begin{array}{l}\text { Extrudate } \\
\text { circularity }\end{array}$} & Intercept & 32,91 & 1 & 32,91 & 117619,55 & $<0,0000^{*}$ \\
\hline & $\mathrm{C}$ & 0,00 & 1 & 0,00 & 0,13 & 0,7216 \\
\hline & $\mathrm{T}$ & 0,00 & 1 & 0,00 & 2,83 & 0,1011 \\
\hline & $\mathrm{C}^{*} \mathrm{~T}$ & 0,00 & 1 & 0,00 & 0,01 & 0,9401 \\
\hline & Error & 0,01 & 36 & 0,00 & & \\
\hline \multirow[t]{5}{*}{ Cell circularity } & Intercept & 3,69 & 1 & 3,69 & 571,21 & $<0,0000^{*}$ \\
\hline & $\mathrm{C}$ & 0,03 & 1 & 0,03 & 4,03 & 0,0523 \\
\hline & $\mathrm{T}$ & 0,00 & 1 & 0,00 & 0,42 & 0,5194 \\
\hline & $\mathrm{C}^{*} \mathrm{~T}$ & 0,03 & 1 & 0,03 & 4,20 & $0,0476^{*}$ \\
\hline & Error & 0,23 & 36 & 0,01 & & \\
\hline \multirow[t]{5}{*}{ Porosity } & Intercept & 95512,12 & 1 & 95512,12 & 1583,46 & $<0,0000^{*}$ \\
\hline & $\mathrm{C}$ & 343,95 & 1 & 343,95 & 5,70 & $0,0223 *$ \\
\hline & $\mathrm{T}$ & 3,33 & 1 & 3,33 & 0,06 & 0,8155 \\
\hline & $\mathrm{C}^{*} \mathrm{~T}$ & 54,45 & 1 & 54,45 & 0,90 & 0,3484 \\
\hline & Error & 2171,48 & 36 & 60,32 & & \\
\hline
\end{tabular}


Research, Society and Development, v. 10, n. 4, e54510414529, 2021

(CC BY 4.0) | ISSN 2525-3409 | DOI: http://dx.doi.org/10.33448/rsd-v10i4.14529

\begin{tabular}{|c|c|c|c|c|c|c|}
\hline \multirow[t]{5}{*}{$\mathrm{L}^{*}$} & Intercept & 51452,87 & 1 & 51452,87 & 110260,10 & $<0,0000^{*}$ \\
\hline & $\mathrm{C}$ & 53,98 & 1 & 53,98 & 115,67 & $<0,0000^{*}$ \\
\hline & $\mathrm{T}$ & 2,46 & 1 & 2,46 & 5,27 & 0,0509 \\
\hline & $\mathrm{C}^{*} \mathrm{~T}$ & 12,26 & 1 & 12,26 & 26,28 & $0,0009 *$ \\
\hline & Error & 3,73 & 8 & 0,47 & & \\
\hline \multirow[t]{5}{*}{$a^{*}$} & Intercept & 578,94 & 1 & 578,94 & 18511,12 & $<0,0000^{*}$ \\
\hline & $\mathrm{C}$ & 2,55 & 1 & 2,55 & 81,48 & $<0,0000^{*}$ \\
\hline & $\mathrm{T}$ & 0,06 & 1 & 0,06 & 2,02 & 0,1933 \\
\hline & $\mathrm{C}^{*} \mathrm{~T}$ & 0,70 & 1 & 0,70 & 22,25 & $0,0015^{*}$ \\
\hline & Error & 0,25 & 8 & 0,03 & & \\
\hline \multirow[t]{5}{*}{$b^{*}$} & Intercept & 4518,65 & 1 & 4518,65 & 76749,86 & $<0,0000^{*}$ \\
\hline & $\mathrm{C}$ & 0,56 & 1 & 0,56 & 9,57 & $0,0148 *$ \\
\hline & $\mathrm{T}$ & 0,13 & 1 & 0,13 & 2,18 & 0,1784 \\
\hline & $\mathrm{C}^{*} \mathrm{~T}$ & 0,03 & 1 & 0,03 & 0,54 & 0,4818 \\
\hline & Error & 0,47 & 8 & 0,06 & & \\
\hline \multirow[t]{5}{*}{ WAI } & Intercept & 698,16 & 1 & 698,16 & 4174,24 & $<0,0000^{*}$ \\
\hline & $\mathrm{C}$ & 1,77 & 1 & 1,77 & 10,60 & $0,0069 *$ \\
\hline & $\mathrm{T}$ & 5,11 & 1 & 5,11 & 30,53 & $0,0001 *$ \\
\hline & $\mathrm{C}^{*} \mathrm{~T}$ & 0,39 & 1 & 0,39 & 2,31 & 0,1542 \\
\hline & Error & 2,0071 & 12 & 0,17 & & \\
\hline \multirow[t]{5}{*}{ WSI } & Intercept & 448,43 & 1 & 448,43 & 2986,69 & $<0,0000^{*}$ \\
\hline & $\mathrm{C}$ & 0,91 & 1 & 0,91 & 6,04 & $0,0302 *$ \\
\hline & $\mathrm{T}$ & 1,22 & 1 & 1,22 & 8,09 & $0,0147 *$ \\
\hline & $\mathrm{C}^{*} \mathrm{~T}$ & 0,63 & 1 & 0,63 & 4,16 & 0,0639 \\
\hline & Error & 1,80 & 12 & 0,15 & & \\
\hline
\end{tabular}

*Significant at $\mathrm{p}<0.05$; SS: sum of square; df: Degrees of freedom; MS: mean of square. Source: Authors.

\subsection{Bowl-life}

Extrudates, when immersed in milk, change texture due to the sudden water absorption, losing its brittle texture, and becoming soaked. The ability of the extrudate to hydrate is correlated with the heat treatment used in the process, as different temperatures provide different degrees of starch gelatinization, resulting in different water absorption rates and softening of the product (Sacchetti et al., 2005).

The bowl-life values ranged between $21.11-22.94 \mathrm{~N}$, with no significant differences $(\mathrm{p}<0.05)$ between the formulations (Table 2), and with no effects of the process variables and their interactions (Table 3). For extruded foods, the initial texture and the texture after immersion in milk should remain similar, with minimal loss of structure during the immersion period, to ensure good crispness characteristics while chewing the product. When comparing the initial hardness and hardness after immersion in milk, the treatments with $8 \%$ of MRC showed close values, with a reduction of $6.5 \%$, demonstrating that at this MRC concentration, it is possible to achieve a stable product with low hydration. For the other treatments, C3-140 and C3-180, a reduction in hardness of 26.9 and $15.0 \%$ were observed, respectively, probably due to the higher starch content of these formulations.

\subsection{Cross-section images analysis}

The image analysis of the cross-section of the extrudates showed a significant effect $(p<0.05)$ of the concentration and temperature for most of the parameters analyzed, except for the circularity of the extrudate. 
The diameter varied between 6.79 and $8.00 \mathrm{~mm}$, with a significant difference between the averages (Table 2), and significant effects of temperature, MRC concentration, and the interaction between these factors. The treatments C8-140 and C8180 had the smallest diameters. It is known that starch has better expansion properties during extrusion, with a tendency to reduce the diameter of the extrudates when fibers replace starch. This behavior was also observed by Oliveira et al. (2015) when incorporating whole grain wheat flour in corn extrudates with jabuticaba powder.

At a process temperature of $180^{\circ} \mathrm{C}$, the extrudates had significantly larger diameters when compared to those subjected to $140{ }^{\circ} \mathrm{C}$ (Table 2, Figure 2). The increase in temperature favored rapid water evaporation, increasing the internal pressure in the extrudates, leading to expansion. Similar behavior was observed for the perimeter and area of the extrudates. Although no significant differences were observed between the porosity of the extrudates, the MRC concentration had a marked effect on this property (Table 3). A tendency towards greater porosity was observed in the treatments with the addition of $8 \%$ MRC. Robin et al. (2012) reported that fibers can change the size of the air cells, leading to an increase in cell wall thickness, which can explain the changes in the circularity of air bubbles (Table 2).

Figure 2. Effects of MRC concentration and process temperature on cross section parameters of rice-based extrudates.
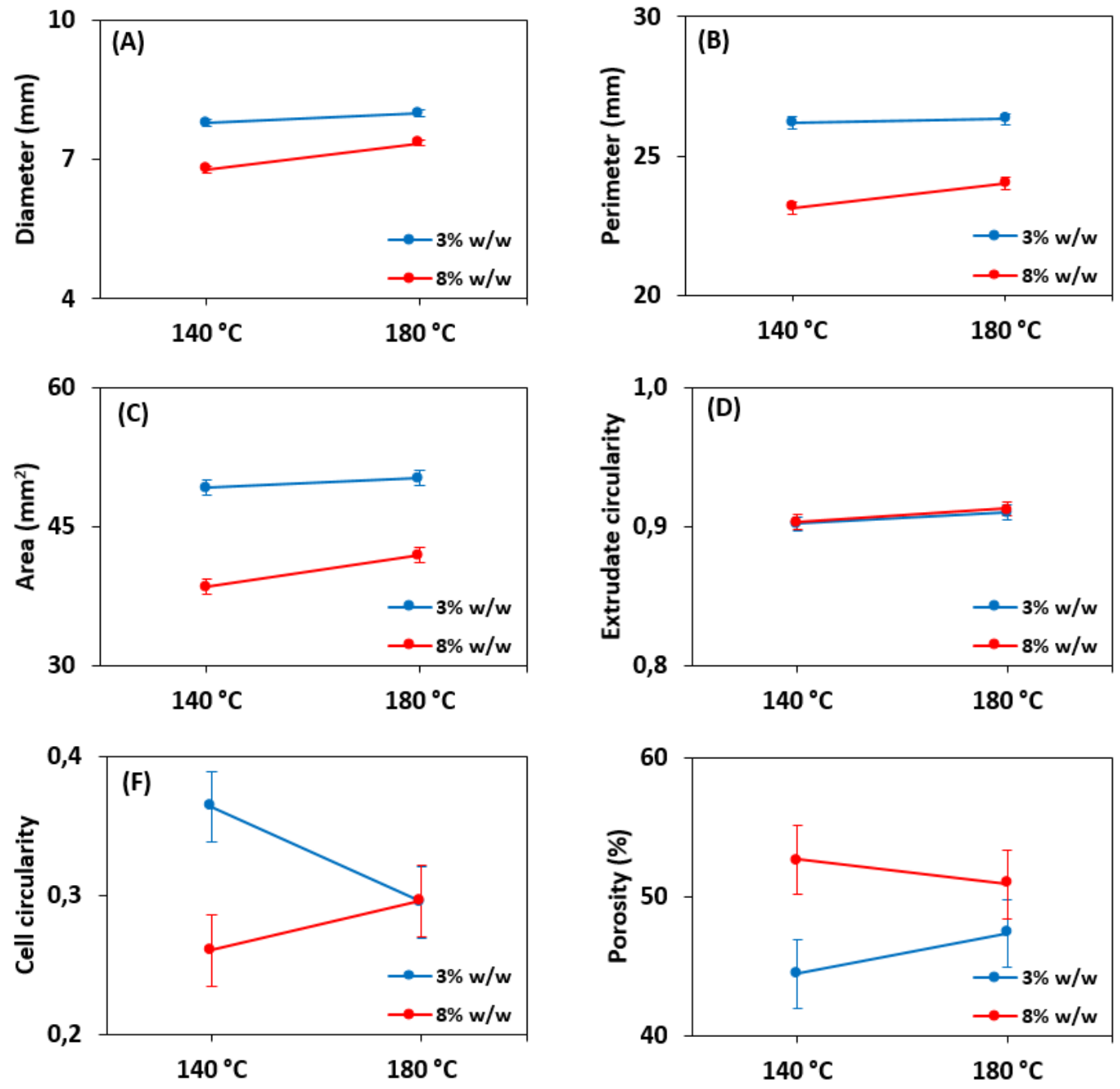

Source: Authors.

\subsection{Instrumental color}

The color of the extruded product plays an important role in consumers' acceptance and is largely affected by the composition of the food matrix and the process conditions (Dalbhagat et al., 2019). RF presented white color ( $\mathrm{L}^{*}: 96.2 \pm 0.14$; 
$\mathrm{a}^{*}:-0.37 \pm 0.02 ; \mathrm{b}^{*}=5.5 \pm 0.06$ ) corroborating with the literature due to the polishing process of rice grains (Becker et al., 2014), while MRC presented luminosity below $50\left(\mathrm{~L}^{*}=43.3 \pm 0.39 ; \mathrm{a}^{*}=10.99 \pm 0.07 ; \mathrm{b}^{*}=15.42 \pm 0.12\right)$. The low luminosity of roasted coffee is due to the roasting process, with the occurrence of the Maillard reaction, and formation of melanoidins, loss of dry matter, and water evaporation from the grains (Spiller, 1998).

The color results of the extrudates are shown in Table 2, with no significant differences observed only for the coordinate b*. Significant differences were observed for the parameters $L^{*}$ (concentration and interaction), a * (concentration and interaction), and $b^{*}$ (concentration) (Table 3). A significant effect of the MRC concentration was expected due to its characteristic color, which affected the color parameters of the extrudates (Figure 3).

Figure 3. Color of the final products obtained with rice flour and micronized-roasted coffee.

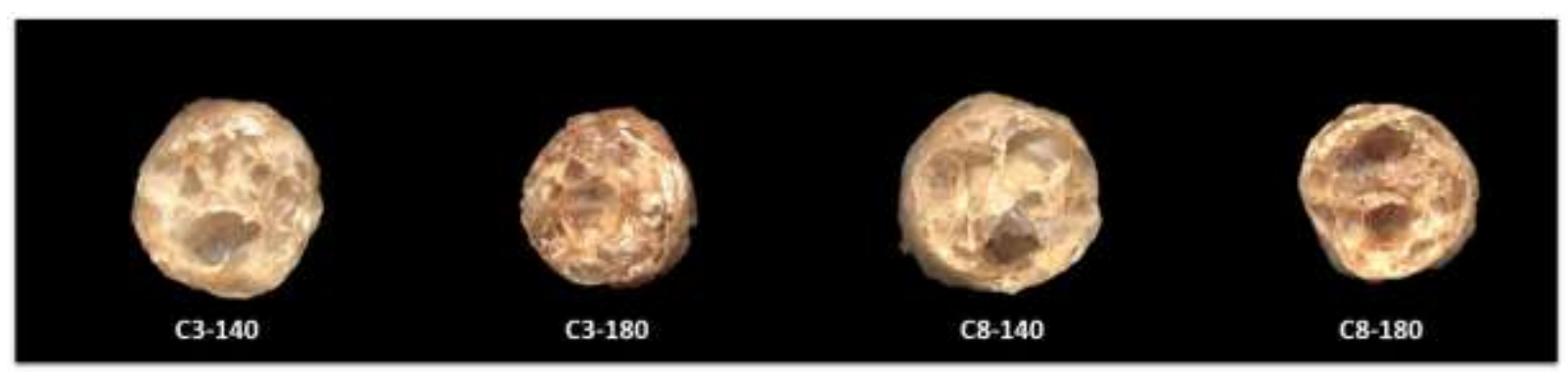

Source: Authors.

For luminosity, the highest values were obtained for the extrudates with $3 \%$, as expected. An increase in process temperature decreased $\mathrm{L}^{*}$ of the treatment made with $8 \% \mathrm{MRC}$ (Figure 4). This reduction may be due to the synergistic effect between high temperature and MRC concentration, degrading the bioactive compounds in the extrudate and producing other compounds with a darker color. Borah et al. (2016) also reported that the Maillard reaction may have favored the reduction of color parameters in rice-seeded banana and carambola pomace blends.

Figure 4. Effects of MRC concentration and process temperature on color parameters of extrudates.
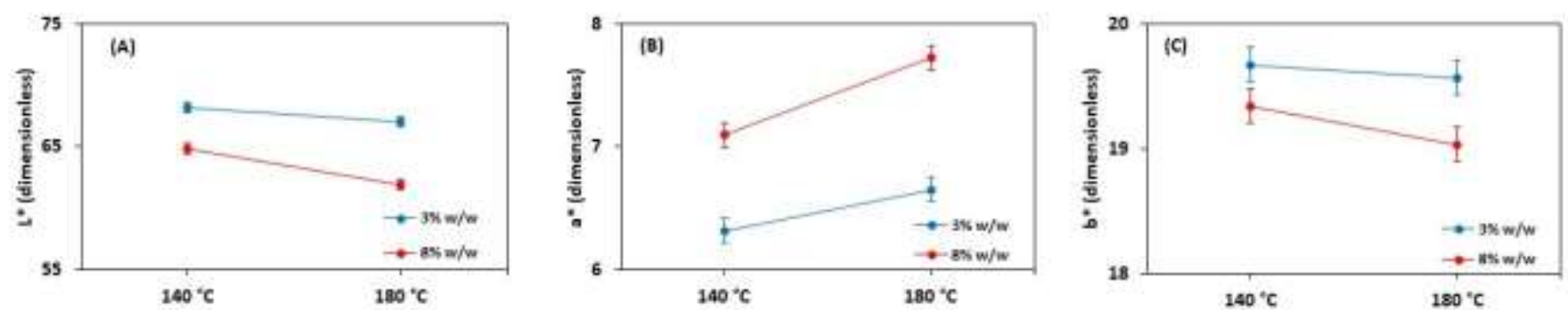

Source: Authors.

\subsection{Water absorption index (WAI) and water solubility index (WSI)}

The WAI indicates the degree of integrity of the starch granule, reflecting the severity of the heat treatment. The loss of the starch structure during the extrusion process leads to the formation of hydrophilic groups available to bind to water molecules, resulting in a reduction in the water absorption capacity (Bouvier \& Campanella, 2014). In the present study, WAI ranged from 5.86 to 7.66, with significant differences $(\mathrm{p}<0.05)$ between the extrudates and a significant effect $(\mathrm{p}<0.05)$ of the temperature and MRC concentration (Table 3). Figure 1 shows a reduction of WAI with increasing the temperature and the MRC concentration. 
Altan et al. (2008) also observed a reduction in WAI of barley-tomato pomace blends with the increase in temperature. During the extrusion, the high temperature can degrade starch molecules, reducing their ability to absorb water, which is improved with a high degree of starch dextrinization (Bouvier \& Campanella, 2014).

The increase in the MRC concentration also reduced the water absorption, probably due to the presence of fibers, less starch availability, and competition of the fibers with the starch for the water available in the system, thus preventing the swelling of the granules. This behavior has already been reported by Robin et al. (2012), and Chávez et al. (2017) in extruded snacks made with sorghum flour and roasted coffee powder.

WSI is used as an indicator of molecular degradation as it measures the amount of soluble compounds released from starch after the extrusion. A high WSI can indicate a good starch digestibility, as it implies the extension of gelatinization and dextrinization (Bouvier \& Campanella, 2014). In the present study, WSI varied from 4.58 to $5.61 \%$, with a significant difference $(\mathrm{p}<0.05)$ between the treatments (Table 2$)$. Also, WSI had a significant effect $(\mathrm{p}<0.05)$ for temperature and MRC concentration (Table 3). Although an increase in WSI was observed with the increase in temperature and MRC concentration, the effect of temperature was more evident for the samples containing higher MRC concentration.

Mesquita et al. (2013) and Taverna et al. (2012) reported that high temperatures led to an increase in WSI of cassava extrudates with flaxseed, and cassava extrudates with quinoa, respectively. The authors pointed out that in addition to starch gelatinization, which results in the release of amylose and amylopectin, dextrinization and other reactions that lead to the formation of low molecular weight compounds can also occur, affecting WSI. Pardhi et al. (2019) observed an increase in WSI in brown rice extrudates with the increase in extrusion temperature.

\subsection{Pasting properties}

The results of the pasting properties allow evaluating the impact of the thermoplastic extrusion on the formulations, which are dependent on the degree of gelatinization and rupture of the starch granule. Figure 5 and Table 4 presents the viscosity profile and the results of this parameter, with significant differences between them $(\mathrm{p}<0.05)$.

Figure 5. Viscosity profile of extrudates containing $\mathrm{RC}$ and $\mathrm{MRC}$ at different concentrations and process temperature.

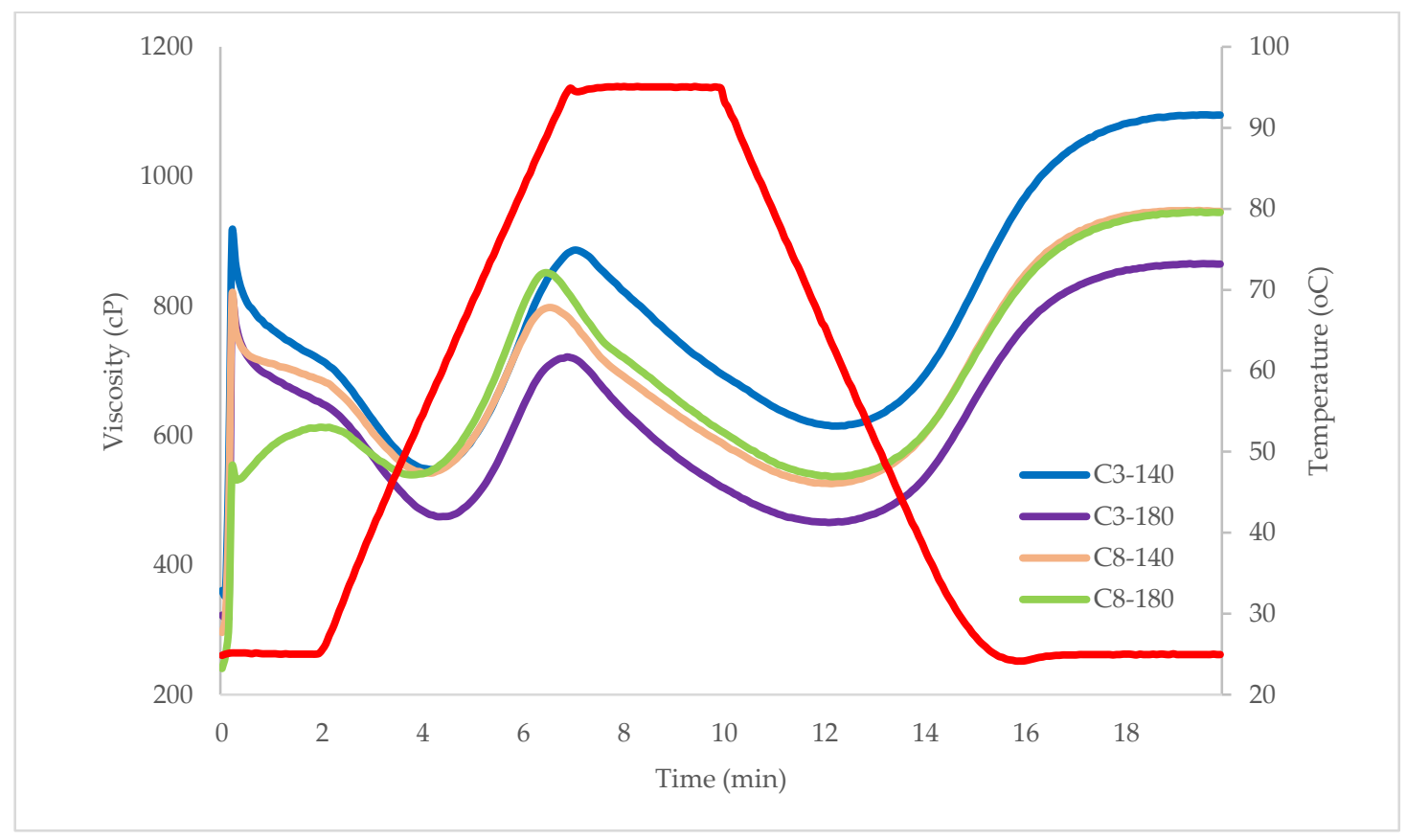

Source: Authors. 
Table 4. Pasting properties of rice-micronized-roasted coffee extrudates ${ }^{1}$.

\begin{tabular}{lcccc}
\hline Parameters (cP) & \multicolumn{3}{c}{ Assays } \\
\cline { 2 - 5 } & C3-140 & C3-180 & C8-140 & C8-180 \\
\hline Cold peak & $936.00 \pm 57.24^{\mathrm{a}}$ & $811.67 \pm 70.71^{\mathrm{b}}$ & $824.33 \pm 44.24^{\mathrm{b}}$ & $629.67 \pm 25.11^{\mathrm{c}}$ \\
Raw peak & $886.00 \pm 11.79^{\mathrm{a}}$ & $721.33 \pm 7.37^{\mathrm{d}}$ & $797.67 \pm 2.31^{\mathrm{c}}$ & $852.00 \pm 12.17^{\mathrm{b}}$ \\
Hold peak & $614.33 \pm 4.04^{\mathrm{a}}$ & $465.67 \pm 4.73^{\mathrm{d}}$ & $525.67 \pm 2.89^{\mathrm{c}}$ & $536.00 \pm 5.57^{\mathrm{b}}$ \\
Breakdown & $271.67 \pm 7.77^{\mathrm{b}}$ & $255.67 \pm 4.51^{\mathrm{c}}$ & $272.00 \pm 2.65^{\mathrm{b}}$ & $316.00 \pm 8.19^{\mathrm{a}}$ \\
Final viscosity & $1094.67 \pm 4.93^{\mathrm{a}}$ & $864.67 \pm 5.51^{\mathrm{c}}$ & $946.00 \pm 2.65^{\mathrm{b}}$ & $944.33 \pm 13.20^{\mathrm{b}}$ \\
Setback & $480.33 \pm 1.53^{\mathrm{a}}$ & $399.00 \pm 8.54^{\mathrm{c}}$ & $420.33 \pm 4.51^{\mathrm{b}}$ & $408.33 \pm 8.14^{\mathrm{c}}$ \\
\hline
\end{tabular}

${ }^{1}$ Values are means \pm standard deviations of triplicate trials. Means with different letters within the same line are significantly different by ScottKnott test $(\mathrm{p}<0.05)$. ns-not significant.

Source: Authors.

Significant effects $(\mathrm{p}<0.05)$ were observed for concentration, temperature, and the interaction between them for all pasting properties studied, except for the cold peak viscosity (concentration and temperature) (Table 5). The cold peak viscosity indicates the ability of the extruded flour to absorb water at room temperature $\left(25^{\circ} \mathrm{C}\right)$, allowing to evaluate the degree of cooking through starch gelatinization and dextrinization caused by the friction between the dough and the screw (Clerici et al., 2019). Despite the higher WSI discussed earlier, severe process conditions and the presence of fibers can lead to a reduction in cold peak viscosity once they do not provide enough viscous material, limiting the starch gelatinization (Robin et al., 2012). 
Table 5. Analysis of variance (ANOVA) of the pasting properties of rice-micronized-roasted coffee extrudates.

\begin{tabular}{|c|c|c|c|c|c|c|}
\hline Parameters & Source & SS & df & MS & F-value & $\mathbf{P}$ \\
\hline \multirow[t]{5}{*}{ Cold peak } & Intercept & 7688002,08 & 1 & 7688002,08 & 2830,63 & $<0,0000^{*}$ \\
\hline & $\mathrm{C}$ & 64680,08 & 1 & 64680,08 & 23,81 & $0,0012^{*}$ \\
\hline & $\mathrm{T}$ & 76320,75 & 1 & 76320,75 & 28,10 & $0,0007^{*}$ \\
\hline & $\mathrm{C}^{*} \mathrm{~T}$ & 3710,08 & 1 & 3710,08 & 1,37 & 0,2761 \\
\hline & Error & 21728,00 & 8 & 2716,00 & & \\
\hline \multirow[t]{5}{*}{ Raw peak } & Intercept & 7956036,75 & 1 & 7956036,75 & 91800,42 & $<0,0000^{*}$ \\
\hline & C & 1344,08 & 1 & 1344,08 & 15,51 & $0,0043^{*}$ \\
\hline & $\mathrm{T}$ & 9130,08 & 1 & 9130,08 & 105,35 & $<0,0000 *$ \\
\hline & $\mathrm{C}^{*} \mathrm{~T}$ & 35970,75 & 1 & 35970,75 & 415,05 & $<0,0000^{*}$ \\
\hline & Error & 693,33 & 8 & 86,67 & & \\
\hline \multirow[t]{5}{*}{ Hold peak } & Intercept & 3440052,08 & 1 & 3440052,08 & 176412,93 & $<0,0000^{*}$ \\
\hline & C & 252,08 & 1 & 252,08 & 12,93 & $0,0070^{*}$ \\
\hline & $\mathrm{T}$ & 14352,08 & 1 & 14352,08 & 736,00 & $<0,0000^{*}$ \\
\hline & $\mathrm{C}^{* \mathrm{~T}}$ & 18960,75 & 1 & 18960,75 & 972,35 & $<0,0000^{*}$ \\
\hline & Error & 155,99 & 8 & 19,49 & & \\
\hline \multirow[t]{5}{*}{ Breakdown } & Intercept & 932976,33 & 1 & 932976,33 & 24128,70 & $<0,0000^{*}$ \\
\hline & $\mathrm{C}$ & 2760,33 & 1 & 2760,33 & 71,39 & $<0,0000^{*}$ \\
\hline & $\mathrm{T}$ & 588,00 & 1 & 588,00 & 15,21 & $0,0045^{*}$ \\
\hline & $\mathrm{C} * \mathrm{~T}$ & 2700,00 & 1 & 2700,00 & 69,83 & $<0,0000^{*}$ \\
\hline & Error & 309,33 & 8 & 38,67 & & \\
\hline \multirow[t]{5}{*}{ Final viscosity } & Intercept & 11114950,08 & 1 & 11114950,08 & 188388,98 & $<0,0000^{*}$ \\
\hline & C & 3570,75 & 1 & 3570,75 & 60,52 & $0,0001^{*}$ \\
\hline & $\mathrm{T}$ & 40252,08 & 1 & 40252,08 & 682,24 & $<0,0000^{*}$ \\
\hline & $\mathrm{C}^{*} \mathrm{~T}$ & 39102,08 & 1 & 39102,08 & 662,75 & $<0,0000^{*}$ \\
\hline & Error & 471,99 & 8 & 59 & & \\
\hline \multirow[t]{5}{*}{ Setback } & Intercept & 2187948,00 & 1 & 2187948,00 & 54023,41 & $<0,0000^{*}$ \\
\hline & C & 1925,33 & 1 & 1925,33 & 47,54 & $0,0001 *$ \\
\hline & $\mathrm{T}$ & 6533,33 & 1 & 6533,33 & 161,32 & $<0,0000^{*}$ \\
\hline & $\mathrm{C}^{*} \mathrm{~T}$ & 3605,33 & 1 & 3605,33 & 89,02 & $<0,0000^{*}$ \\
\hline & Error & 324,00 & 8 & 40,50 & & \\
\hline
\end{tabular}

*Significant at $\mathrm{p}<0.05$; SS: sum of square; df: Degrees of freedom; MS: mean of square. Source: Authors.

The loss of the starch granule structure reduces the swelling capacity during heating, presenting low viscosity at $95{ }^{\circ} \mathrm{C}$. However, a raw peak viscosity higher or similar to cold peak viscosity indicates the existence of intact starch granules or partially preserved starchy structure (Bouvier \& Campanella, 2014). This result can be seen in the viscosity profile of the samples (Figure 5) and in the findings of Chávez et al. (2017). The existence of intact granules may be associated with a significant plasticizer concentration, such as the lipids in raw materials, which prevent starch degradation or provide a low shear rate (Bouvier \& Campanella, 2014).

When the maximum rupture of the available starch granules is reached by stirring the medium at a constant temperature, there is a decrease in viscosity. However, the increase in the MRC concentration increased both raw peak and hold peak viscosities (Figure 6) for the treatments at $180{ }^{\circ} \mathrm{C}$, probably due to the contribution of fibers in the preserved starchy structure that still present the swelling capacity. 
Figure 6. Effects of MRC concentration and process temperature on pasting properties of extrudates.
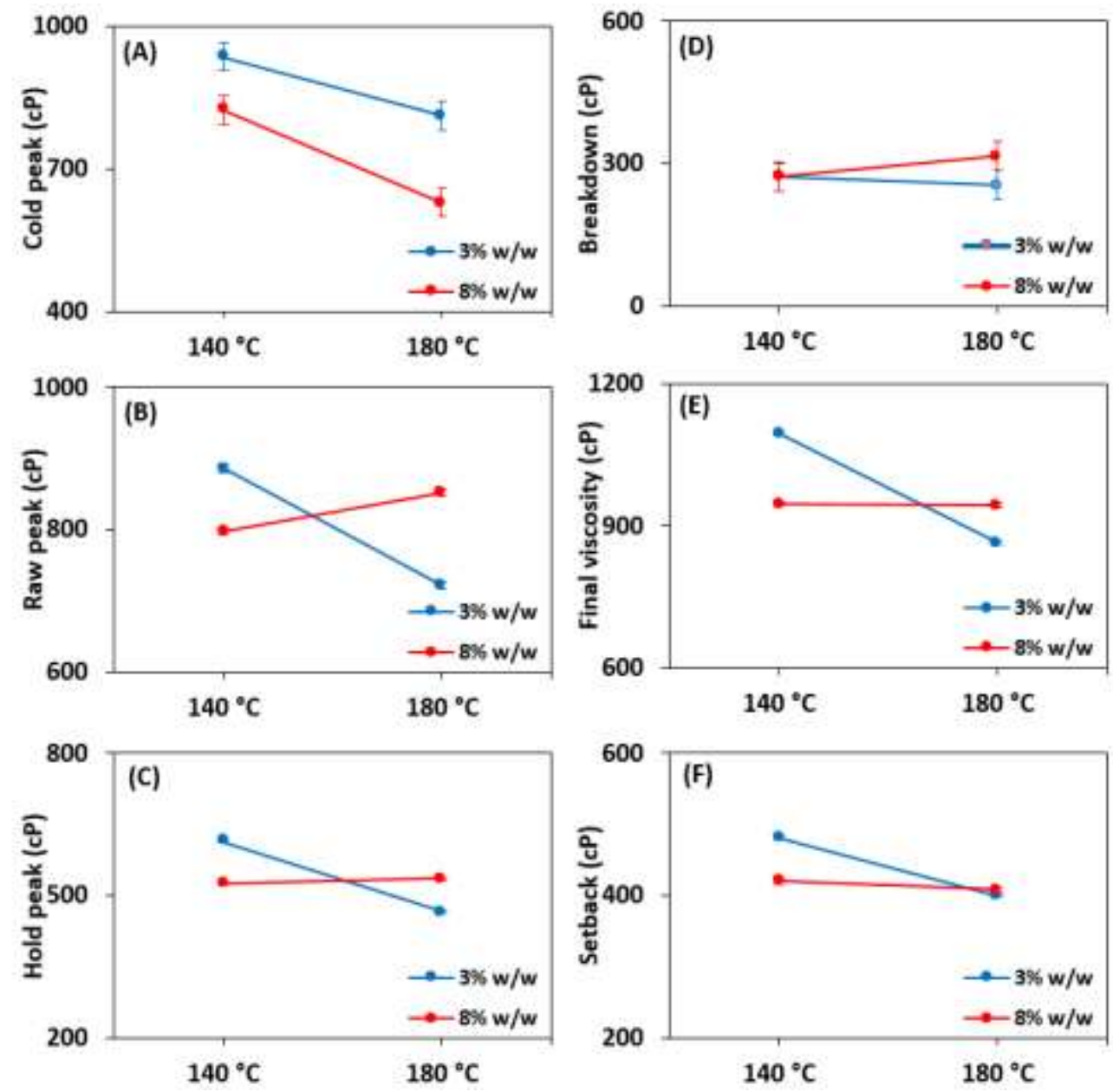

Source: Authors.

Breakdown refers to the stability of starch paste to heating and mechanical shear while setback viscosity, refers to the behavior of starch during cooling by the recrystallization of the amylose and amylopectin chains through hydrogen bonds, leading to the formation of precipitates and syneresis, with an increase in final viscosity (Clerici et al., 2019). An increase in breakdown and reduction of setback viscosity values was observed for the formulations made with $8 \%$ of MRC (Figure 5). This behavior is a consequence of the variation in the starch and fiber ratio of the formulations, with the effect of the concentration being more noticeable for breakdown viscosity of C8-140 and C8-180, while the temperature more significantly affected the setback viscosity of C3-140 and C3-180.

Although the final viscosity $\left(\mathrm{V}_{\text {final }}\right)$ is related to the moisture and the temperatures used in the extrusion process, the screw speed, the particle size, and the proximate composition of the raw material can also affect this parameter (Clerici et al., 2019). WAI is also associated with $\mathrm{V}_{\text {final, }}$, as a high absorption rate leads to a higher $\mathrm{V}_{\text {final }}$ (Bouvier \& Campanella, 2014). Due to the estimated WAI values for the treatments (Table 2), a reduction in the final viscosity between C3-140 and C3-180 was expected, as well as the maintenance of the final viscosity between C8-140 and C8-140.

\section{Conclusion}

The partial replacement of micronized-roasted coffee by rice flour affected the technological properties of the extrudates, especially the color, expansion index, and texture parameters, due to the presence of fibers and color compounds from the raw material, as a result of coffee roasting and the Maillard reaction during thermoplastic extrusion. The effect of 
temperature was more significant for water absorption and solubility indexes, while the other parameters were affected by the combination of temperature and MRC concentration, such as expansion index.

The results showed that the C8-140 and C8-180 assays presented technological characteristics suitable for an expanded extruded product. They showed similar expansion to the assays with 3\% MRC, with lower hardness and stability in water absorption and bowl-life. At this concentration, there may be a greater sensory acceptance for the probable contribution to the flavour. I any case, sensory attributes should be investigated. As for the process temperatures, the next step would be to study the retention of bioactive compounds.

Therefore, understanding the factors that interfere in producing ready-to-eat extruded products with MRC makes it possible to perform a better process optimization, resulting in a product with technological and sensory characteristics more accepted by consumers looking for a healthier and more pleasurable diet.

\section{Acknowledgments}

The authors thank the scholarships by CNPq to Ulliana Marques Sampaio (131074/2015-6) and Pedro H. Campelo (CNPq - 150826/2019-2), the financial support provided by FAEPEX/Unicamp, and the research support by ITAL (Food Technology Institute). They also thank SL Alimentos (Mauá da Serra/PR) and Ipanema Coffees (Alfenas/MG) for the donation of the raw materials.

\section{References}

Anderson, R. A. (1982). Water Absorption and Solubility and Amylograph Characteristics of Roll-Cooked Small Grain Products. Cereal Chemistry, 59(4), 265269.

Borah, A., Mahanta, C. L., \& Kalita, D. (2016). Optimization of process parameters for extrusion cooking of low amylose rice flour blended with seeded banana and carambola pomace for development of minerals and fiber rich breakfast cereal. J Food Sci and Technol., 53(1), 221-232. https://doi.org/10.1007/s13197015-1772-9

Bouvier, J.-M., \& Campanella, O. H. (2014). Extrusion processing technology: Food and non-food biomaterials. Wiley-Blackwell.

Chávez, D. W. H., Ascheri, J. L. R., Carvalho, C. W. P., Godoy, R. L. O., \& Pacheco, S. (2017). Sorghum and roasted coffee blends as a novel extruded product: Bioactive compounds and antioxidant capacity. Journal of Functional Foods, 29, 93-103. https://doi.org/10.1016/j.jff.2016.12.012

Clerici, M. T. P. S., Sampaio, U. M., \& Schmiele, M. (2019). Identification and Analysis of Starch. In M. T. P. S. Clerici \& M. Schmiele (Eds.), Starches for Food Application (pp. 23-69). Acadmic Press. https://doi.org/10.1016/B978-0-12-809440-2.00002-2

Dalbhagat, C. G., Mahato, D. K., \& Mishra, H. N. (2019). Effect of extrusion processing on physicochemical, functional and nutritional characteristics of rice and rice-based products: A review. Trends in Food Science and Technology, 85, 226-240. https://doi.org/10.1016/j.tifs.2019.01.001

Pereira, G. V. de M., Neto, D. P. de C., Magalhães Júnior, A. I., Do Prado, F. G., Pagnoncelli, M. G. B., Karp, S. G., \& Soccol, C. R. (2020). Chemical composition and health properties of coffee and coffee by-products. In F. Toldrá (Ed.), Advances in Food and Nutrition Research (pp. 65-96). Elsevier. https://doi.org/10.1016/bs.afnr.2019.10.002

Dean, A., Voss, D., \& Draguljić, D. (2017). Design and Analysis of Experiments. (2a ed.). Springer International Publishing. https://doi.org/10.1007/978-3-319$52250-0$

Ding, Q. B., Ainsworth, P., Tucker, G., \& Marson, H. (2005). The effect of extrusion conditions on the physicochemical properties and sensory characteristics of rice-based expanded snacks. Journal of Food Engineering, 66(3), 283-289. https://doi.org/10.1016/j.jfoodeng.2004.03.019

Eerikainen, T., \& Linko, P. (1989). Extrusion cooking modeling control, and optimization. In C. Mercier, P. Linko, \& J. M. Harper (Eds.), Extrusion Cooking (pp. 157-204). AACC International.

Elleuch, M., Bedigian, D., Roiseux, O., Besbes, S., Blecker, C., \& Attia, H. (2011). Dietary fibre and fibre-rich by-products of food processing: Characterisation, technological functionality and commercial applications: A review. Food Chemistry, 124(2), 411-421. https://doi.org/10.1016/j.foodchem.2010.06.077

Euromonitor. (2020). Wellness Redefined: Healthy Eating in a Post-Coronavirus World. https://www.euromonitor.com/wellness-redefined-healthy-eating-ina-post-coronavirus-world/report

Faubion, J. M., \& Hoseney, R. C. (1986). High-Temperature Short-Time Extrusion Cooking of Wheat Starch and Flour. II. Effect of Protein and Lipid on Extrudate Properties. Cereal Chemistry, 59, 533-537.

ICO, I. C. O. (2020). Coffee Market Prices Continued to Climb in December. Retrived January 15, 2021, from http://www.ico.org/documents/cy2019-20/cmr1219-e.pdf 
Mesquita, C. de B., Leonel, M., \& Mischan, M. M. (2013). Effects of processing on physical properties of extruded snacks with blends of sour cassava starch and flaxseed flour. Food Science and Technology, 33(3), 404-410. https://doi.org/10.1590/S0101-20612013005000073

Obradović, V., Babić, J., Šubarić, D., Ačkar, Đ., \& Jozinović, A. (2014). Improvement of nutritional and functional properties of extruded food products. Journal of Food and Nutrition Research, 53, 189-206.

Oliveira, L. C., Rosell, C. M., \& Steel, C. J. (2015). Effect of the addition of whole-grain wheat flour and of extrusion process parameters on dietary fibre content, starch transformation and mechanical properties of a ready-to-eat breakfast cereal. International Journal of Food Science \& Technology, 50(6), 1504-1514. https://doi.org/10.1111/ijfs. 12778

Oliveira, L. C., Schmiele, M., \& Steel, C. J. (2017). Development of whole grain wheat flour extruded cereal and process impacts on color, expansion, and dry and bowl-life texture. LWT - Food Science and Technology, 75, 261-270. https://doi.org/10.1016/j.1wt.2016.08.064

Pardhi, S. D., Singh, B., Nayik, G. A., \& Dar, B. N. (2019). Evaluation of functional properties of extruded snacks developed from brown rice grits by using response surface methodology. Journal of the Saudi Society of Agricultural Sciences, 18(1), 7-16. https://doi.org/10.1016/j.jssas.2016.11.006

Paula, A. M., \& Conti-Silva, A. C. (2014). Texture profile and correlation between sensory and instrumental analyses on extruded snacks. Journal of Food Engineering, 121, 9-14. https://doi.org/10.1016/j.jfoodeng.2013.08.007

Perecin, D., \& Cargnelutti Filho, A. (2008). Comparisonwise and experimentwise effects in fatorial experiments interactions. Ciência e Agrotecnologia, 32(1), 68-72. https://doi.org/10.1590/S1413-70542008000100010

Riaz, M. N., \& Rockey, G. J. (2012). Extrusion problems solved. Woodhead Publishing.

Robin, F., Schuchmann, H. P., \& Palzer, S. (2012). Dietary fiber in extruded cereals: Limitations and opportunities. Trends in Food Science \& Technology, 28(1), 23-32. https://doi.org/10.1016/j.tifs.2012.06.008

Sacchetti, G., Pittia, P., \& Pinnavaia, G. G. (2005). The effect of extrusion temperature and drying-tempering on both the kinetics of hydration and the textural changes in extruded ready-to-eat extrudates during soaking in semi-skimmed milk. International Journal of Food Science and Technology, 40(6), 655-663. https://doi.org/10.1111/j.1365-2621.2005.00976.x

Shah, F.-H., Sharif, M. K., Bashir, S., \& Ahsan, F. (2019). Role of healthy extruded snacks to mitigate malnutrition. Food Reviews International, 35(4), 299323. https://doi.org/10.1080/87559129.2018.1542534

Silva, R. F. da, Pereira, R. G. F. A., Ascheri, J. L. R., \& Ascheri, D. P. R. (2013). Technological properties of precooked flour containing coffee powder and rice by thermoplastic extrusion. Food Science and Technology 33(1), 7-13.

Silván, J. M., Morales, F. J., \& Saura-Calixto, F. (2010). Conceptual Study on Maillardized Dietary Fiber in Coffee. Journal of Agricultural and Food Chemistry, 58(23), 12244-12249. https://doi.org/10.1021/jf102489u

Spiller, G. A. (1998). Caffeine. California, USA: CRC Press.

Taverna, L. G., Leonel, M., \& Mischan, M. M. (2012). Changes in physical properties of extruded sour cassava starch and quinoa flour blend snacks. Food Science and Technology, 32(4), 826-834. https://doi.org/10.1590/s0101-20612012005000113

The Food Market Insitute, F. (2019). U.S. grocery shopper trends 2019. https://www.fmi.org/docs/default-source/webinars/trends-a-look-at-today\%27s-groceryshopper-slides-pdf.pdf.

Zhu, F., Du, B., Li, R., \& Li, J. (2014). Effect of micronization technology on physicochemical and antioxidant properties of dietary fiber from buckwheat hulls. Biocatalysis and Agricultural Biotechnology, 3(3), 30-34. https://doi.org/10.1016/j.bcab.2013.12.009 